\title{
Búcsú D. Mátai Máriától
}

\author{
(1945-2020)
}

Ismét eggyel kevesebben lettünk. Nehéz leírni az ilyen mondatot még akkor is, ha tudjuk, hogy D. Mátai Mária betegsége miatt már hosszú évek óta nem volt jelen a tanszéki és a szakmai élet mindennapjaiban. Most, a visszavonhatatlan véglegesség tudatában szomorú szívvel búcsúzunk tőle, az embertől, a munkatárstól, tudományos kutatótól, tanártól az Eötvös Loránd Tudományegyetem magyar nyelvészei és a Magyar Nyelvtudományi Társaság nevében.

Mátai Mária 1945. november 22-én született Szombathelyen. Iskoláit szülővárosában végezte. A gimnázium utolsó évében az Országos Középiskolai Tanulmányi Versenyen orosz nyelvböl elért helyezésével felvételi vizsga nélkül nyert felvételt az ELTE magyar-orosz szakára, ahol 1969-ben szerzett diplomát. A magyar nyelvészet és ezen belül a nyelvtörténet iránti érdeklődése folyamatosan alakult ki egyetemi tanulmányai során, és már szakdolgozatában kijelölte azt a fő kutatási irányt (a szófajtörténet és ezen belül a határozószók kérdéskörének vizsgálata), amely egész életpályája során meghatározó volt, és amellyel maradandót alkotott. 1970-ben megvédte bölcsészdoktori disszertációját, amelynek kiváló eredményéért kitüntetéses (vörös) diplomája után megkapta a Sub auspiciis rei publicae popularis feliratú aranygyürüt. 1985-ben a nyelvtudomány kandidátusa fokozatot szerezte meg, 1997-ben habilitált, 2008-ban az MTA doktori fokozatot nyerte el. Részt vett a Magyar nyelv történeti nyelvtana munkálataiban (MNyT.), egy egyetemi jegyzet (H. BOTTYÁNFY ÉVÁval, HORVÁTH MÁRIÁval és KOROMPAY KLÁRÁval [H. BOTTYÁNFFY HORVÁTH - KOROMPAY - D. MÁTAI 1981 stb.]) és nyelvtörténet-tankönyvek írásában. Széles körü nyelvészeti érdeklődéséről ő maga így írt: ,a grammatika- illetőleg szófajtörténeten kívül jó néhány egyéb témával is foglalkoztam: a középiskolai anyanyelvi neveléssel, tudománytörténettel, a leíró nyelvészet egyes kérdéseivel, a figura etymologica grammatikai és stilisztikai vonatkozásaival, a csángó nyelvjárás egyes jelenségeivel. Egyik legkedvesebb témám az 1433-as másolatban fennmaradt verses imádságunknak, a Laskai soroknak a monografikus feldolgozása volt" (MÁTAI 2009: 145).

Mátai Mária igazi tanáregyéniség volt. Nemcsak a tananyagot megtanítani, hanem a hallgatóknak az anyanyelv szeretetét átadni is akarta. Nagy hatással volt tanítványaira, akiknek szakmai életútját évek múltán is figyelemmel kísérte. Nem véletlen, hogy közülük többet is a kutatói pályán indított el.

Mátai Mária a tanár, a kutató mellett igazi közösségi ember is volt. Részt vett a Kar életében: több cikluson keresztül volt tagja a Kari Tanácsnak, 1976 és 1979 között az ELTE Egyetemi Tanácsának is. A Magyar Nyelvtudományi Társaságnak 1976-tól választmányi tagja volt. 1998-ban Széchenyi Professzori Ösztöndíjban, 2002-ben Széchenyi István Ösztöndíjban részesült, 2009-ben Apáczai Csere János-díjjal tüntették ki.

Kedves, barátságos, mindenki felé nyitott természete a kollégák irányában is megmutatkozott. Amikor Hajdú Mihállyal a fiatal és fiatalos nyelvészek baráti körének, a később Bokor néven ismertté vált csoportnak a megalakításán gondolkodtunk, természetesen adódott, hogy Marikával együtt legyünk a mozgatói ennek a baráti körnek. Szerteágazó 
jó kapcsolatai révén a Bokor szakmai vitái, beszélgetései háttereként szétküldött Bokor levelek stenciles sokszorosítását is viszonylag könnyen meg lehetett oldani a korszakra jellemző cenzúrás világban is. A Bokor sikerén felbuzdulva a Kar más szakos fiatal oktatói is szervezkedni kezdtek. Így jött létre a Fiatal Oktatók Klubja, a Fiók, amelynek a szervezői között ugyancsak megtaláltuk öt is.

Mátai Mária kedves, vidám, barátságos személyiségét, de törhetetlen munkakedvét a betegség, a hosszú évtizedeken keresztül fellépő súlyos migrénes rohamok sem törték meg. Emlékezetünkben így örizzük meg az utókor számára.

\section{Hivatkozott irodalom}

H. BotTyÁnfFy ÉVA - Horváth MÁria - Korompay KlÁRA - D. MÁtAi MÁRIA 1981. Bevezetés az egyetemi nyelvészeti tanulmányokba. Tankönyvkiadó, Budapest. (Sok utánnyomással.)

Mátai Mária 2009. E./1. In: Kontra MikLÓs - BAKRó-NAgY MARIANNE szerk., A nyelvészetről - egyes szám, első személyben 2. A Szegedi Tudományegyetem Bölcsészettudományi Kara, Szeged. 143-145.

TNyt. = A magyar nyelv történeti nyelvtana. I. A korai ómagyar kor és elözményei. II/1. A kései ómagyar kor. Morfematika. II/2. A kései ómagyar kor. Mondattan. Szöveggrammatika. Főszerk. BENKŐ LORÁND. Akadémiai Kiadó, Budapest, 1991-1995.

ZELLIGER ERZSÉBET

ELTE Eötvös Loránd Tudományegyetem

\section{Búcsú Kótyuk Istvántól}

(1934-2020)

A kárpátaljai magyar tudományosság szegényebb lett: életének 86. évében eltávozott közülünk dr. Kótyuk István, a II. Rákóczi Ferenc Kárpátaljai Magyar Főiskola tanszékvezető professzora, az MTA külső köztestületi tagja, a Kárpátaljai Magyar Akadémiai Tanács alapító tagja. Gyászolja a kárpátaljai magyar nyelvésztársadalom, gyászolják kollégái, tanítványai, tisztelői.

Kótyuk István - elismert magyar nyelvész, müfordító, lexikográfus, számos, a kárpátaljai magyar tannyelvű iskolák számára készült tankönyv szerzője. A szovjet éra nehéz időinek tanúja és részese. Az őszinteség és becsületesség kísérte élete végéig. Évtizedek során a szülőföld tiszteletére, az anyanyelv és a kultúra ápolására nevelte tanítványait.

1934. január 11-én született az akkor Csehszlovákiához tartozó, jelenleg az ukrajnai Ungvári járás területén található Nagyrát településen. Elemi iskolai tanulmányait helyben végezte. 1949-ben felvételt nyert a Munkácsi Tanítóképzőbe, mely 1950-ig Huszton müködött. 1953-ban szerzett elemi iskolai tanítói diplomát, s még ugyanebben az évben az Ungvári Pedagógiai Főiskola magyar nyelvészeti szakán kezdett el tanulni. A pedagógiai főiskolát hamarosan megszüntették, tanulmányait ezért az Ungvári Állami Egyetemen folytatta, ahol 1958-ban szerzett orosz nyelv és irodalom szakos tanári 